Association for Information Systems AIS Electronic Library (AISeL)

ICIS 1981 Proceedings

International Conference on Information Systems

1981

\title{
Firm Size and the Characteristics of Computer Use
}

William H. DeLone

University of California

Follow this and additional works at: http://aisel.aisnet.org/icis 1981

\section{Recommended Citation}

DeLone, William H., "Firm Size and the Characteristics of Computer Use" (1981). ICIS 1981 Proceedings. 19.

http://aisel.aisnet.org/icis1981/19

This material is brought to you by the International Conference on Information Systems (ICIS) at AIS Electronic Library (AISeL). It has been accepted for inclusion in ICIS 1981 Proceedings by an authorized administrator of AIS Electronic Library (AISeL). For more information, please contact elibrary@aisnet.org. 


\title{
Firm Size and the Characteristics of Computer Use*
}

\author{
William H. DeLone \\ University of California
}

\begin{abstract}
Although researchers have examined the differences between managing large and small businesses, few studies have explored these differences in terms of managing the use of computers. Nearly all of the important MIS research is being conducted in large organizations. The results of these research efforts may not apply to smaller firms if their MIS environments are indeed different. Thus, the present focus of most MIS research may be missing the needs and problems of thousands of small business users.

Several MIS articles suggest that small businesses face unique problems in the management of their computer resources, but thus for the evidence cited is anecdotal. Few research efforts have studied this issue scientifically. This study tests the contention that small businesses use computers differently than large businesses by examining a sample of Los Angeles manufacturing firms of various sizes.
\end{abstract}

The proposition that computer usage characteristics are different in firms of different sizes is tested using five specific hypotheses:

- Smaller firms have been using computers for a shorter period of time than have large firms.

- Smaller firms are more highly dependent on external programming services.

- Smaller firms allocate a smaller portion of their total revenues for electronic data processing.

- Within the EDP budget, smaller firms spend a larger portion of their EDP expenditures on computer hardware, as opposed to software and personnel expenses.

- Small businesses can implement a decision to invest in computers faster than large businesses.

*This article will appear in Volume 5, Number 4 of the MIS Quarterly, to be published in December 1981. 
The survey research method was used to test these five hypotheses. A systematic, random survey of two hundred and forty firms was selected from approximately 2,400 Los Angeles manufacturing firms which are listed in the California Manufacturing Register. Eightyfour firms were found to be using computers and were the focus of this survey. For the final analysis, seventy-five firms provided sufficient data to be useful in the study.

In addition to data relating to the five hypotheses, the firms were asked the following: (1) what type of computer support they have (inhouse, service bureau, etc.), (2) what is their most important business application processed by computer, (3) what benefits they are deriving from computers, and (4) what has been their major problem in the use of computers.

The key variable, firm size, was measured by the number of employees.' This measure of size is consistent with the current Small Business Administration (SBA) classification scheme for manufacturing firms. Pearson correlation coefficients were computed to measure the strength of associotion between firm size and the other hypothesis variables. Where indicated, partial correlation coefficients were computed between firm size and the hypothesis variables while controlling for the age of the firm's EDP operation. Analysis of variance tests were also computed to test for differences between firms which were classified as small or larger.

The results of the various statistical tests showed that firm size is: (1) directly related to the size of the firm's computer operations, (2) inversely related to the amount of external programming that is used, (3) directly related to the portion of revenues allocated to electronic data processing (EDP), and (4) inversely related to the percentage of EDP costs that are used for computer equipment. No relationship was found between firm size and the amount of time required to implement the firm's initial decision to use computers.

This survey produced four additional findings about the relationship between firm size and computer use. The age of the EDP operation and firm size are associated with whether a firm uses "inhouse" computers, service bureaus, timesharing, or parent company EDP services. Firms using parent company services were the more experienced computer users, and smaller firms were using service bureaus. Secondly, the age of the computer operation, but not the firm's size, is associated with a firm's more important computer application. The more experienced computer users cited more "advanced" applications (for example, sales analysis, job costing, and material requirements planning) as being most important while less experienced firms found more "basic" applications (for example, payroll, inventory, and accounts receivable) to be their most important. Thirdly, it could not be determined whether firms of different size derive different benefits from their use of computers. 
Finally, small firms do experience different computer related problems than larger firms. Small firms are more concerned with poor quality software and with poor service from service bureaus, while larger firms complain of problems with poor user understanding and with information system complexity.

These findings have important implications. Small businesses need to evaluate the payoff of their "most important" applications. Small businesses need qualified assistance in making difficult software decisions. Small businesses are probably not allocating their EDP dollars effectively, spending too much on equipment and not enough on software and personnel. Finally, operation size is an important control variable to consider in the design of MIS research projects. From these findings it should be clear that more computer based management information systems research should be conducted in small business settings. 